\title{
Interaction of Glutamate- and Adenosine-Induced Decrease of Acetylcholine Quantal Release at Frog Neuromuscular Junction
}

\author{
S. ADÁMEK ${ }^{1}$, A. V. SHAKIRZYANOVA ${ }^{2}$, A. I. MALOMOUZH ${ }^{2}$, N. V. NAUMENKO ${ }^{3}$, \\ F. VYSKOČIL ${ }^{4,5}$
}

${ }^{1}$ Third Surgical Department, First Faculty of Medicine, Charles University, Prague, ${ }^{2}$ Institute of Biochemistry and Biophysics, Russian Academy of Sciences, Kazan, ${ }^{3}$ Department of Normal Physiology, Kazan State Medical University, Kazan, Russia, ${ }^{4}$ Department of Animal Physiology, Faculty of Sciences, Charles University, Prague, and ${ }^{5}$ Institute of Physiology, Academy of Sciences of the Czech Republic, Prague, Czech Republic

Received April 28, 2010

Accepted July 9, 2010

\section{Summary}

In a frog neuromuscular preparation of $m$. sartorius, glutamate had a reversible dose-dependent inhibitory effect on both spontaneous miniature endplate potentials (MEPP) and nerve stimulation-evoked endplate potentials (EPP). The effect of glutamate on MEPP and EPP is caused by the activation of metabotropic glutamate receptors, as it was eliminated by MCPG, an inhibitor of group I metabotropic glutamate receptors. The depression of evoked EPP, but not MEPP frequency was removed by inhibiting the NO production in the muscle by L-NAME and by ODQ that inhibits the soluble NO-sensitive guanylyl cyclase. The glutamate-induced depression of the frequency of spontaneous MEPP is apparently not caused by the stimulation of the NO cascade. The particular glutamate-stimulated NO cascade affecting the evoked EPP can be down-regulated also by adenosine receptors, as the glutamate and adenosine actions are not additive and application of adenosine partially prevents the further decrease of quantal content by glutamate. On the other hand, there is no obvious interaction between the glutamatemediated inhibition of EPP and inhibitory pathways triggered by carbacholine and ATP. The effect of glutamate on the evoked EPP release might be due to NO-mediated modulation (phosphorylation) of the voltage-dependent $\mathrm{Ca}^{2+}$ channels at the presynaptic release zone that are necessary for evoked quantal release and open during EPP production.

\section{Key words}

Endplate potentials • Guanylyl cyclase • Carbacholine • ATP • NO

\section{Corresponding authors}

František Vyskočil, Institute of Physiology, Academy of Sciences of the Czech Republic, Vídeňská 1083, Prague-4, Czech Republic. E-mail: Vyskočil@biomed.cas.cz and

Artem Malomouzh, Institute of Biochemistry and Biophysics, Russian Academy of Sciences, Kazan, Russia, E-mail: artur57@list.ru

\section{Introduction}

Changes in the number of quanta either released at rest or during nerve stimulation are a manifestation of synaptic plasticity, the phenomenon underlying the fine regulation of the activities of the nervous system at the cellular level (Vyskočil 2003). It was found that, along with a principal neurotransmitter, there are a number of other substances released from the nerve ending that can strengthen or weaken the process of neurotransmitter secretion. In the most studied model of synaptic contact, the vertebrate neuromuscular junction, the feedback mechanisms were found that regulate the release of acetylcholine (ACh). In particular, the action ACh itself, its co-transmitter ATP and ATP-hydrolyzation product adenosine were studied on quantal and non-quantal ACh (Galkin et al. 2001, Nikolsky et al. 2004, Silinsky 2004, Veggetti et al. 2008, Burnstock 2009, Voss 2009). In addition, the interaction of the purinergic and cholinergic pathways was described at the neuromuscular synapse of 
both cold- (Shakirzyanova et al. 2006) and warm-blooded (Oliveira et al. 2002) animals. Evidence has emerged that glutamate, a neurotransmitter whose synaptic role was previously demonstrated and analyzed mostly in the CNS (Baudry 2009, Hur et al. 2009) can participate in the regulation of $\mathrm{ACh}$ release in peripheral vertebrate synapses, in particular in the non-quantal release of ACh at the rodent endplate (Urazaev et al. 1998, Malomouzh et al. 2003). The aim of this work was to study the mechanism of glutamate action on quantal spontaneous and nerve-evoked endplate potentials at the frog neuromuscular junction and to assess the possible interactions of the glutamate pathway with several other modulators - carbacholine, ATP and adenosine.

\section{Materials and Methods}

Experiments were performed on isolated neuromuscular preparations of the sartorius muscle of the frog Rana ridibunda. The preparation, pinned to the bottom of a translucid sylgard chamber, was superfused continuously at $20^{\circ} \mathrm{C}$ with Ringer solution containing (in mM) $\mathrm{NaCl}$ 115.0, $\mathrm{KCl} 2.5, \mathrm{CaCl}_{2}$ 1.8, $\mathrm{NaHCO}_{3}$ 2.4; $\mathrm{pH}=7.2-7.4$ (Novotný et al. 1962). Suprathreshold stimuli of $0.1 \mathrm{~ms}$ duration were applied to the nerves at $2 \mathrm{~s}$ intervals via a pair of platinum electrodes located in a small adjacent moist chamber (Samigullin et al. 2003). This arrangement minimized the stimulus artifact. Muscle resting potentials and endplate potentials were recorded in the muscle fibre synaptic zone by standard intracellular microelectrodes filled with $2.5 \mathrm{M} \mathrm{KCl}$ (tip resistance 8$15 \mathrm{M} \Omega$ ) under visual control by dissection microscope (x200).

To record the nerve-evoked endplate potentials (EPP), a modified solution with a lower concentration of $\mathrm{Ca}^{2+}(0.45 \mathrm{mM})$ and higher content of $\mathrm{Mg}^{2+}(6 \mathrm{mM})$ was used to decrease the quantal content of the EPP. This $\mathrm{Ca}^{2+} / \mathrm{Mg}^{2+}$ ratio lowered the number of quanta and size of EPP below the muscle spike threshold depolarization and eliminated the muscle contraction. The quantal content was less than 10 under this $\mathrm{Ca}^{2+} / \mathrm{Mg}^{2+}$ ratio and therefore no correction for the non-linear summation of quanta was used (McLachlan and Martin 1981). EPP and miniature end-plate potentials (MEPP) were recorded 10-15 min prior and during 30-60 min of drug application using the standard intracellular microelectrode technique.

The quantal content of the EPP was assessed by dividing the average EPP amplitude by the average amplitude of MEPP recorded in the same muscle fiber.
For MEPP and EPP analysis, at least 200 events both before (control) and after drug application were captured in the frequency band $0-3000 \mathrm{~Hz}$ in each fiber as well as at least 50 EPP for calculating the quantal content, where the mean EPP amplitude was divided by the mean MEPP (McLachlan and Martin 1981). Spontaneous quantal secretion was analyzed as an average frequency of the MEPP (Kovyazina et al. 2003). All drugs and chemicals used were from Sigma (St. Louis, MO, USA) with the exception of (S)-a-methyl-4-carboxyphenylglycine (MCPG) and 1H-[1,2,4]Oxadiazolo[4,3-a]quinoxalin-1one (ODQ), which were purchased from Tocris Cookson Inc (Ballwin, MT, USA). Hemoglobin was reduced with sodium dithionate, dialyzed and kept frozen in aliquots at $-20{ }^{\circ} \mathrm{C}$ (Martin et al. 1985, Mukhtarov et al. 2000). The results were expressed as the mean \pm S.E.M. of experiments on at least three endplates from different preparations. Statistical significance was evaluated using Wilcoxon's non-parametric test at a probability level of $\mathrm{p}<0.05$.

\section{Results}

Before glutamate or other drugs were applied, the mean MEPP frequency was $0.87 \pm 0.12 \mathrm{~s}^{-1}(\mathrm{n}=14)$ and quantal content was $5.7 \pm 1.9 \quad(\mathrm{n}=15)$. Glutamate at concentrations of 20,100 and $500 \mu \mathrm{M}$ had no significant effect on the resting membrane potential (control value $-82.4 \pm 1.3 \mathrm{mV} \mathrm{n}=155$, inside minus, and $-81.0 \pm 1.6 \mathrm{mV}$, $\mathrm{n}=52$ in the presence of $500 \mu \mathrm{M}$ glutamate) but resulted in a concentration-dependent and reversible (within $30 \mathrm{~min}$ wash) reduction of the spontaneous MEPP frequency and decrease in the quantum content of the evoked EPP (Fig. 1). The maximal decrease in the MEPP frequency was found in the presence of $100 \mu \mathrm{M}$ glutamate, where the average MEPP frequency declined to $67.1 \pm 7.9 \%(\mathrm{n}=7, \mathrm{p}<0,05)$ without any changes in amplitude, rise time and decay time of the MEPP (Fig. 1B). The observed drop in evoked EPP amplitude was therefore due to presynaptic reduction of the quantal content, i.e. a lower number of quanta released by every nerve impulse. EPP amplitude depression had a maximum at $500 \mu \mathrm{M}$ glutamate when quantal content was decreased to $75.7 \pm 5.8 \%$ of the control (Fig. 1B).

Metabotropic glutamate receptors (mGluR) have been recently found in the frog endplate (Pinard et al. 2003). To verify whether these mGluRs could be mediating the drop in quantal release by glutamate, muscles were pretreated with $500 \mu \mathrm{M} \mathrm{MCPG}$, an 

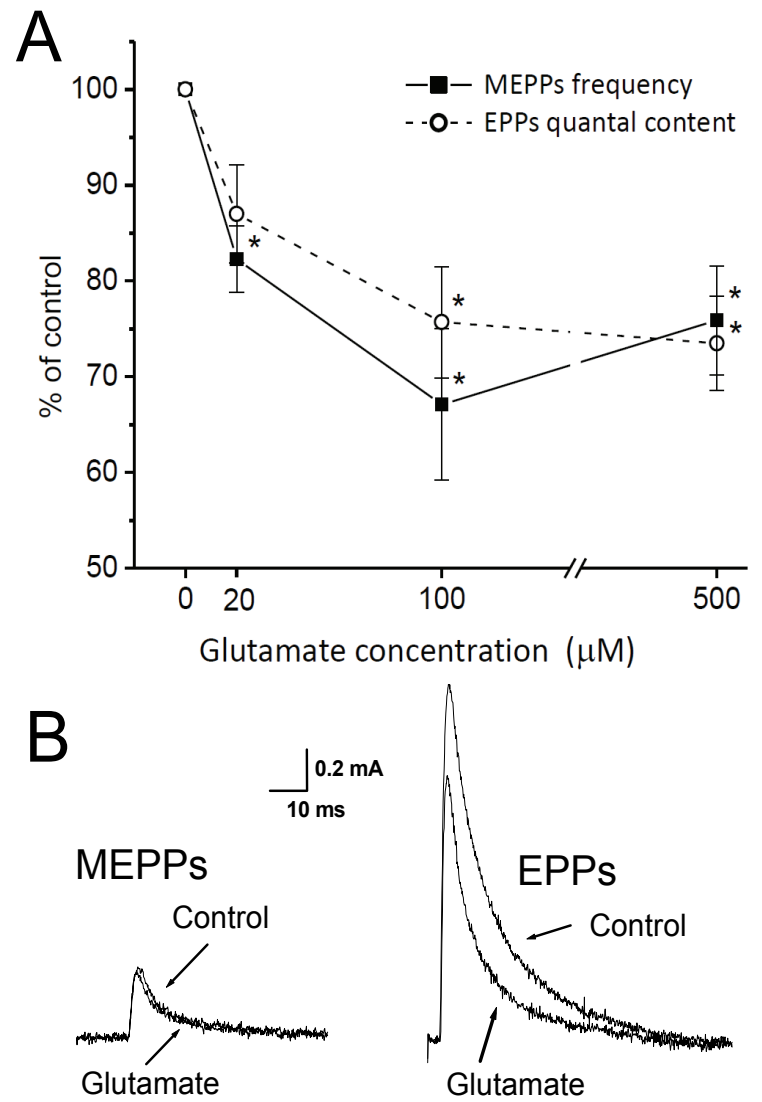

Fig. 1. Effect of 20,100 and $500 \mu \mathrm{M}$ glutamate (abscissa) on MEPP frequency ( $\mathbf{A}$, black squares) and on quantal content of nerve-evoked EPPs ( $A$, empty circles). B - mean recordings of five MEPPs and EPPs before (Control) and $30 \mathrm{~min}$ after $100 \mu \mathrm{M}$ glutamate application. Data expressed as percentage of control value before $30 \mathrm{~min}$ application of glutamate (ordinate). * significant difference $(p<0.05)$ between control and experiment.

inhibitor for group I metabotropic glutamate receptors $\left(\mathrm{mGlu}_{1 \alpha}\right.$ and $\mathrm{mGlu}_{5 \mathrm{a}}$ ) (Doherty et al. 1999), prior to glutamate application.

The MCPG completely abolished the inhibitory effects of $500 \mu \mathrm{M}$ glutamate on both MEPP frequency, which was $98.8 \pm 5.6 \%$ of the control, and EPP quantal content, which was $103.4 \pm 8.1 \%$ of the control $(n=3)$. This confirms the significant participation of mGluR1 in the drop in quantal ACh release (Pinard and Robitaille 2003).

The modulatory effect of glutamate is similar to the depressive action of cholinergic agonists and purines on quantal ACh release at the frog endplate (Ribeiro et al. 1996, Nikolsky et al. 2004, Shakirzyanova et al. 2006).

The question arises whether there are some common output pathways in quantal release regulation by these three receptor systems, as was earlier demonstrated in CNS (Ribeiro et al. 2003) and in the case of nonquantal ACh release (Vyskočil et al. 2009). The effects of three representative agonists on quantal release were therefore compared in the absence and presence of the glutamate.

$10 \mu \mathrm{M}$ carbacholine (cholinergic agonist) (Ciani and Edwards 1963), $100 \mu \mathrm{M}$ ATP (purinergic $\mathrm{P}_{2}$ receptors agonist) (Burnstock 2007) and $100 \mu \mathrm{M}$ adenosine $\left(\mathrm{P}_{1}\right.$ receptors agonist) (Sawyok 2007) reduced the MEPP frequency to $54.3 \pm 3.8 \%, 47.3 \pm 3.3 \%$ and $40.8 \pm 4.0 \%$, and EPP quantal content to $68.3 \pm 3.9 \%$, $53.9 \pm 4.9 \%$ and $55.9 \pm 4.9 \%$ of the control values, respectively (Fig. 2). When $100 \mu \mathrm{M}$ glutamate was added $30 \mathrm{~min}$ after the drugs application, this proportional drop in MEPP frequency and EPP quantal content remained unchanged with carbacholine and ATP (Fig. 2) On the other hand, the depressive effect of adenosine was significantly smaller, only to $61.0 \pm 5.2 \%$ for MEPP frequency and to $69.4 \pm 4.7 \%$ of the controls for the EPP quantal content. Thus the adenosine and glutamate metabotrophic pathways can at least partially interact; if the glutamate pathway is saturated, the effect of adenosine is smaller. One possible interactive pathway might be the NO cascade, NO synthase in particular (Ribeiro et al. 2003, Pinard and Robitaille 2008), because it was found that NO might to a certain extent mediate the suppressive effect of adenosine on the quantal secretion of $\mathrm{ACh}$ at the frog neuromuscular synapse (Thomas and Robitaille 2001). The NO synthase was therefore inhibited by $100 \mu \mathrm{M}$ N-nitro-L-arginine methyl ester (LNAME) (Hobbs and Gibson 1990).

The smaller production of NO led to an increase in MEPP frequency by $23.2 \pm 6.4 \%$, (Fig. 3, column 5) and partially reverted the inhibitory action of adenosine on MEPP frequency by $38.5 \pm 7.3 \%$ (Fig. 3, columns 1 and 2). The most profound elimination of glutamate activity was observed in evoked responses. EPP amplitude and correspondingly the quantal content was $103.0 \pm 4.1 \% \quad(n=4)$ of the control when $100 \mu \mathrm{M}$ L-NAME was applied $30 \mathrm{~min}$ before $100 \mu \mathrm{M}$ glutamate. While our work was in progress, Pinard and Robitaille (2008) published similar data on the NO-dependent inhibition of evoked EPP by glutamate.

On the other hand, the glutamate-induced decrease of the spontaneous MEPP frequency was not significantly prevented by the inhibition of NO production (Fig. 3, columns 3 and 4). This indicates that in spontaneous quantal release, glutamate still exhibits its inhibitory effect even during a reduction in $\mathrm{NO}$ production.

As shown in previous papers, the main source of 


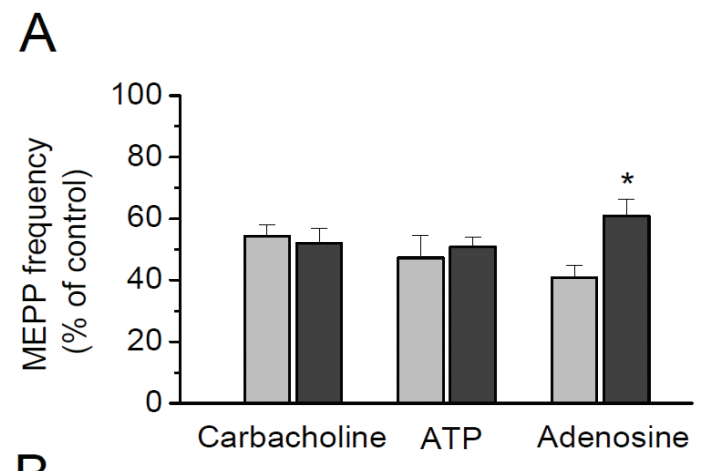

B

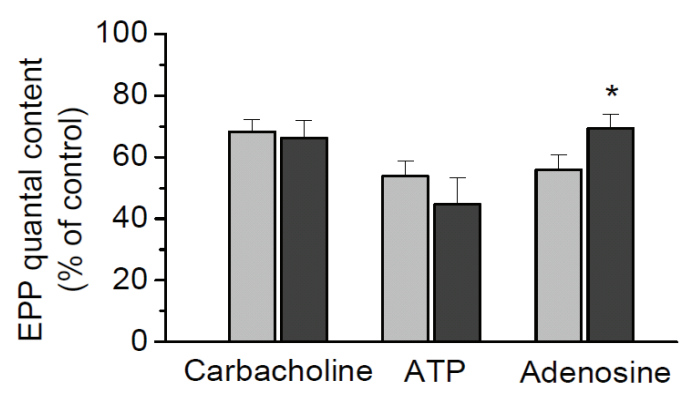

Fig. 2. Effect of $10 \mu \mathrm{M}$ carbacholine, $100 \mu \mathrm{M}$ ATP and $100 \mu \mathrm{M}$ adenosine on the frequency of spontaneous (MEPP) (A) and stimulation-evoked EPP (B) recorded after $30 \mathrm{~min}$ of their application (gray columns), and then $30 \mathrm{~min}$ after their application together with $100 \mu \mathrm{M}$ glutamate (black columns). Gray columns - EPP quantal content expressed as percentage of controls before drug application, or percentage of new level when gray columns are taken as $100 \%$ before glutamate plus the drug application. Asterisk - difference between control and experiment $(p<0.05)$. Because carbacholine depolarizes the RMP by $5-10 \mathrm{mV}$, only those experiments with carbacholine application were taken into analysis when the distribution of MEPP amplitudes in the presence of this ACh analogue still fitted by bell-shaped Gaussian function indicating that there was no loss of low-amplitude signals.

presynaptic NO regulation of quantal and non-quantal release is muscle NO synthase (Pinard and Robitaille 2003, Urazaev et al. 1995). To further assess whether the glutamate-evoked presynaptic decrease in the MEPP frequency is really independent of the generation of NO in the muscle, solutions of glutamate were applied to muscles $5 \mathrm{~min}$ after the exposure to $20 \mu \mathrm{M}$ reduced hemoglobin. As hemoglobin binds NO in the synaptic cleft, it should prevent extracellular NO from accumulating and exerting its presynaptic action (Barinaga 1991, Hu and El-Fakahany 1993, Meller and Gebhart 1993). Indeed, hemoglobin did not affect the $100 \mu \mathrm{M}$ glutamate-induced decreases in MEPP frequency, which was $72.3 \pm 6.1 \%(n=5, p>0.05)$, when compared with the corresponding controls without hemoglobin (70.1 $\pm 3.5 \%$ ) (Fig. 1). On the other hand, hemoglobin almost completely eliminated the glutamateinduced decrease in EPP quantal content. The values

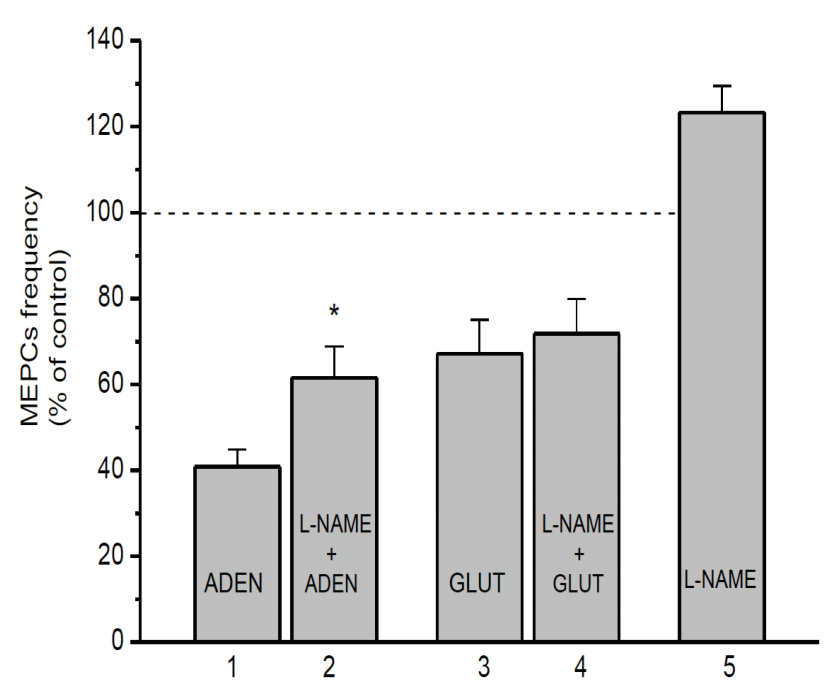

Fig. 3. Effect of NOS inhibitor $100 \mu \mathrm{M}$ L-NAME (column 5), $100 \mu \mathrm{M}$ adenosine (ADEN, columns 1 and 2) and $100 \mu \mathrm{M}$ glutamate (GLUT, columns 3 and 4 ) in the absence (columns 1 and 3) and presence of $100 \mu \mathrm{M}$ L-NAME (columns 2 and 4) on MEPP frequency. Data are expressed as percentage of control value before $30 \mathrm{~min}$ application of the drugs, either alone or together with L-NAME (ordinate). * - significant difference between control and experiment $(p<0.05)$.

were $70.0 \pm 6.0 \%$ and $102.5 \pm 5.1 \%$ of the control $(n=5)$ in muscles exposed to glutamate and glutamate plus hemoglobin, respectively. Hemoglobin applied alone for 60 min caused a small but significant $(\mathrm{p}<0.05)$ increase in the EPP quantal content to $110.2 \pm 3.6 \%(\mathrm{n}=5)$, which indicates that there is certain resting production of NO controlling ACh-evoked quantal release. The MEPP frequency remained unchanged during the presence of 20 $\mu \mathrm{M}$ hemoglobin $(98.3 \pm 7.2 \%$ of the control). The application of guanylyl cyclase inhibitor $2 \mu \mathrm{M}$ ODQ (Garthwaite et al. 1995, Urazaev et. al. 1996) led to the elimination of the glutamate effect on EPP but not on the MEPP frequency. The quantal content was $97.7 \pm 1.3 \%$ of the control in the presence of $100 \mu \mathrm{M}$ glutamate and $2 \mu \mathrm{M}$ ODQ $(\mathrm{n}=5)$. Similarly as L-NAME, the ODQ slightly increased the MEPP frequency by $8.2 \pm 2.0 \%$ $(n=5)$. Nevertheless, other tentative phosphorylation pathways should be tested to trace the possible presynaptic action of glutamate via mGluR1 on the MEPP frequency. Experiments in this regard are underway.

\section{Discussion}

The application of exogenous glutamate resulted in a concentration-dependent reversible decrease in both MEPP frequency and quantal content of EPP. Because no 
changes were found in MEPP amplitude, rise time and decay time constant, the inhibitory action of glutamate is presynaptic, in agreement with a previous report (Pinard and Robitaille 2008). Besides the NMDA receptors pharmacologically defined during non-quantal ACh release (Urazaev et al. 1995, 1998), metabotropic glutamate receptors were found in the frog endplate (Pinard et al. 2003). The action of glutamate was eliminated in the presence of metabotropic glutamate receptor blocker MCPG. It confirms the participation of this class of glutamate receptors in the regulation of both spontaneous and evoked quantal release.

The presynaptic effect of glutamate is similar to the effects of cholinergic and purinergic agonists (Van der Kloot et al. 1997, Grishin et al. 2005). The effects of three representative agonists - carbacholine, ATP and adenosine - on quantal release showed that carbacholineand ATP-induced reduction of the MEPP frequency and EPP quantum content remained unchanged in the presence of glutamate, whereas the depressive effect of adenosine was significantly smaller. This means that metabotropic effect of glutamate is mostly independent of cholinergic and ATP-ergic regulation, whereas the adenosine (A1 receptors) and glutamate metabotrophic effects at least partially interact. When the glutamate pathway is saturated, the adenosine effect is much smaller. Previous studies on the presynaptic adenosine and carbacholine-evoked depression of MEPP frequency suggested that membrane-delimited cross-talk did not occur directly between A1 and M2 receptors. Rather, there should be a convergence of signals triggered by either of these metabotropic receptors to a common intracellular pathway in the nerve terminal (Shakirzyanova et al. 2006).

Such an interaction can be mediated by the NO cascade (Ribeiro et al. 2003, Pinard and Robitaille 2008). It was found that NO partly mediates the suppressive effect of adenosine on the quantal secretion of ACh at the frog and rat neuromuscular synapses (Thomas and Robitaile 2001, Galkin et al. 2001). Glutamate has been shown to also regulate non-quantal release in rats and mice (for a review see Vyskočil et al. 2009) through NMDA postsynaptic receptors and the NO cascade (Urazaev et al. 1995, 1998, 1999). In the experiments presented here, the inhibition of the NO synthase and lower production of NO caused an increase in MEPP frequency (Fig. 3) and partially reverted the inhibitory action of adenosine, but not glutamate, on MEPP frequency (Fig. 3). However, the EPP amplitude and EPP quantal content completely recovered when L-NAME was applied together with glutamate. This indicates that in spontaneous quantal release, glutamate still exhibits its inhibitory effect in the absence of NO production while the inhibition of evoked ACh release by glutamate strongly depends on NO synthase activity.

The observed glutamate inhibition of the evoked vesicular release, i.e. EPP quantal content, is clearly a mGluR1- and NO-dependent process and our observations are in agreement with recent data on bathapplied and stimulation-evoked release of endogenous glutamate from nerve terminals and Schwann cells (Pinard and Robitaille 2008). Glutamate action on evoked release is not only prevented by NO synthase inhibition but also by extracellular hemoglobin, an NO scavenger. This points to a muscular origin of the NO that has to cross the synaptic cleft before entering the nerve ending and activating the soluble guanylyl cyclase involved in the $\mathrm{Ca}^{2+}$-dependent release of quanta.

The detailed mechanism of the influence of the NO cascade on evoked quantal release is unclear. Pinard and Robitaille (2008) simply stated that NO diffuses to the presynaptic terminal where it affects the evoked quantal release of the ACh. One possibility is that NOtriggered guanylyl cyclase-induced phosphorylation hinders the openings of the voltage-dependent $\mathrm{Ca}^{2+}$ channels that are linked to release sites during a nerve spike. This might diminish the necessary amount of intracellular $\mathrm{Ca}^{2+}$ in the active zone for quanta release (Gilmanov et al. 2008). A less likely possibility is that the glutamate triggers an NO- and cGMP-induced phosphorylation of proteins that are directly involved in vesicle fusion and non-quantal release (Doležal et al. 1983, Vyskočil et al. 1983). The glutamate only lowers the evoked $\mathrm{Ca}^{2+}$-dependent synchronized release of quanta (EPP), not spontaneous release of quanta, despite the fact that similar scaffolds like $\mathrm{v}$ - and t-SNAREs apparently exist at the sites of spontaneous and evoked quanta release (Jackson and Chapman 2006). What might be different is the regulation of the spontaneous and evoked release by $\mathrm{Ca}^{2+}$ channels and $\mathrm{Ca}^{2+}$ entry. MEPP frequency is less sensitive to rapid intracellular $\mathrm{Ca}^{2+}$ elevation via voltage-sensitive $\mathrm{Ca}^{2+}$ channels, at least at rest, and the number of spontaneous quanta depends rather on the "tonic" or residual level of $\mathrm{Ca}^{2+}$ (Rahamimoff and Yaari 1973, Searl and Silinsky 2005). Thus, despite the molecular membrane machineries for spontaneous and evoked release being apparently identical, the inhibition of glutamate action was only 
demonstrated here with evoked $\mathrm{Ca}^{2+}$-channel-dependent $E P P$, indicating altered $\mathrm{Ca}^{2+}$ entry.

If the glutamate-induced decrease of spontaneously released quanta is not influenced by the inhibition of NO synthase, why then does L-NAME alone (and in experiments with the inhibition of soluble guanylyl cyclase as well) increase the MEPP frequency? This can be explained as an indirect consequence of the absence of NO production. We found earlier that postsynaptic resting membrane potential is regulated by a NO-dependent, furosemide-sensitive transporter (Urazaev et al. 1999, Vyskočil 2003). When the NO production is inhibited, e.g. by L-NAME or during the early postdenervation period, the $\mathrm{Cl}^{-}$transporter starts to transmit $\mathrm{Cl}^{-}$ions into the muscle fiber and the synaptic zone is depolarized by 7-10 mV (Urazaev et al. 1999, Vyskočil 2003). One can suppose that a similar slight depolarization might also develop in the nerve terminal when NO synthase is inhibited. Because the MEPP frequency is potential-dependent and increases with depolarization (Losavio and Muchnik 1997) the more frequent spontaneous release is observed during reduced NO production. The dissipation of the evoked and spontaneous transmitter release control was also found in central glutamatergic synapses (Pan et al. 1996) and does not contradict contemporary views on neuromuscular microphysiology (Holohean and Magleby 2009). Physiologically, it is important not to regulate the spontaneous subthreshold release too much, but rather the nerve-evoked quanta. The NO-dependent cross-talk between glutamate, cholinergic and purinergic postsynaptic and presynaptic receptors could take place during intense synaptic activity and thereby ensure the proper neuromuscular transmission.

\section{Conflict of Interest}

There is no conflict of interest.

\section{Acknowledgements}

Supported by Russian Foundation for Basic Research (RFBR) 07-04-01656 and 10-04-01255, Russian President MK-8017.2010.4, Scientific Schools of Russia SS-64631.2010.07 for AS, AM and NN. FV was supported by IAA500110905, GAČR 202/09/0806 and AV0Z 0110509.

\section{References}

BARINAGA M: Is nitric oxide the "retrograde messenger"? Science 254: 1296-1297, 1991.

BAUDRY M: Multi-level control of ionotropic glutamate receptor function. Cellscience 6: 79, 2009.

BURNSTOCK G: Purine and pyrimidine receptors. Cell Mol Life Sci 64: 1471-1483, 2007.

BURNSTOCK G: Purinergic cotransmission. Exp Physiol 94: 20-24, 2009.

CIANI S, EDWARDS C: The effect of acetylcholine on neuromuscular transmission in the frog. J Pharmacol Exp Ther 142: 21-23, 1963.

DOHERTY AJ, COLLINGRIDGE GL, JANE DE: Antagonist activity of alpha-substituted 4-carboxyphenylglycine analogues at group I metabotropic glutamate receptors expressed in CHO cells. Br J Pharmacol 126: 205-210, 1999.

DOLEŽAL V, VYSKOČIL F, TUČEK S: Decrease of the spontaneous non-quantal release of acetylcholine from the phrenic-nerve in botulinum-poisoned rat diaphragm. Pflugers Arch 397: 319-322, 1983.

GALKIN AV, GINIATULLIN RA, MUKHTAROV MR, ŠVANDOVÁ I, GRISHIN SN, VYSKOČIL F: ATP but not adenosine inhibits nonquantal acetylcholine release at the mouse neuromuscular junction. Eur $J$ Neurosci 13: 2047-2053, 2001.

GARTHWAITE SOUTHAM E, BOULTON CL, NIELSEN EB, SCHMIDT K, MAYER B: Potent and selective inhibition of nitric oxide-sensitive guanylyl cyclase by 1H-[1,2,4]oxadiazolo[4,3-a]quinoxalin-1-one. Mol Pharmacol 48: 184-188, 1995.

GILMANOV IR, SAMIGULLIN DV, VYSKOČIL F, NIKOLSKY EE, BUKHARAEVA EA: Modeling of quantal neurotransmitter release kinetics in the presence of fixed and mobile calcium buffers. J Comput Neurosci 25 : 296-307, 2008.

GRISHIN S, SHAKIRZYANOVA A, GINIATULLIN A, AFZALOV R, GINIATULLIN R: Mechanisms of ATP action on motor nerve terminals at the frog neuromuscular junction. Eur J Neurosci 21: 1271-1279, 2005. 
HOBBS AJ, GIBSON A: L-N $\mathrm{N}^{\mathrm{G}}$-nitro-arginine and its methyl ester are potent inhibitors of non-adrenergic, noncholinergic transmission in the rat anococcygeus. Br J Pharmacol 100: 749-752, 1990.

HOLOHEAN AM, MAGLEBY KL: Neuromuscular junction (NMJ): presynaptic short-term plasticity of neuromuscular transmission. Encyclopedia of Neuroscience, Elsevier, Amsterdam, 2009, pp 629-634.

HU J, EL-FAKAHANY EE: Role of intercellular and intracellular communication by nitric oxide in coupling of muscarinic receptors to activation of guanylate cyclase in neuronal cells. J Neurochem 61: 578-585, 1993.

HUR EE, EDWARDS RH, ROMMER E, ZABORSZKY L: Vesicular glutamate transporter 1 and vesicular glutamate transporter 2 synapses on cholinergic neurons in the sublenticular gray of the rat basal forebrain: a double-label electron microscopic study. Neuroscience 164: 1721-1731, 2009.

JACKSON MB, CHAPMAN ER: Fusion pores and fusion machines in $\mathrm{Ca}^{2+}$-triggered exocytosis. Annu Rev Biophys Biomol Struct 35: 135-160, 2006.

KOVYAZINA IV, NIKOLSKY EE, GINIATULLIN RA, ADÁMEK S, VYSKOČIL F: Dependence of miniature endplate current on kinetic parameters of acetylcholine receptors activation: a model study. Neurochem Res $\mathbf{2 8}$ : 443-448, 2003.

LOSAVIO A, MUCHNIK S: Spontaneous acetylcholine release in mammalian neuromuscular junctions. Am J Physiol 273: C1835-C1841, 1997.

MALOMOUZH AI, MUKHTAROV MR, NIKOLSKY EE, VYSKOČIL F, LIEBERMAN EM, URAZAEV AK: Glutamate regulation of non-quantal release of acetylcholine in the rat neuromuscular junction. $J$ Neurochem 85: 206-213, 2003.

MARTIN W, VILLANI GM, JOTHIANANDAN D, FURCHGOTT RF: Selective blockade of endothelium-dependent and glyceryl trinitrate-induced relaxation by hemoglobin and by methylene blue in the rabbit aorta. J Pharmacol Exp Ther 232: 708-716, 1985.

MCLACHLAN EM, MARTIN AR: Non-linear summation of end-plate potentials in the frog and mouse. $J$ Physiol Lond 311: 307-324, 1981.

MELLER ST, GEBHART GF: Nitric oxide (NO) and nociceptive processing in the spinal cord. Pain 52: 127-136, 1993.

MUKHTAROV MR, URAZAEV AK, NIKOLSKY EE, VYSKOČIL F: Effect of nitric oxide and NO synthase inhibition on nonquantal acetylcholine release in the rat diaphragm. Eur J Neurosci 12: 980-986, 2000.

NIKOLSKY EE, VYSKOČIL F, BUKHARAEVA EA, SAMIGULLIN D, MAGAZANIK LG: Cholinergic regulation of the evoked quantal release at frog neuromuscular junction. J Physiol Lond 560: 77-88, 2004.

NOVOTNÝ I, VYKLICKÝ L, BERÁNEK R: Potassium and caffeine induced increase of oxygen consumption in frog muscle and its inhibition by drugs. Physiol Bohemoslov 11: 277-284, 1962.

OLIVEIRA L, TIMÓTEO MA, CORREIA-DE-SÁ P: Modulation by adenosine of both muscarinic $\mathrm{M}_{1}$-facilitation and $\mathrm{M}_{2}$-inhibition of $\left[{ }^{3} \mathrm{H}\right]$-acetylcholine release from the rat motor nerve terminals. Eur J Neurosci 15: 1728-1736, 2002.

PAN Z-H, SEGAL MM, LIPTON S: Nitric oxide-related species inhibit evoked neurotransmission but enhance spontaneous miniature synaptic currents in central neuronal cultures. Proc. Natl Acad Sci USA 93: 15423$15428,1996$.

PINARD A, ROBITAILLE R: Nitric oxide dependence of glutamate-mediated modulation at a vertebrate neuromuscular junction. Eur J Neurosci 28: 577-587, 2008.

PINARD A, LÉVESQUE S, VALLÉE J, ROBITAILLE R: Glutamatergic modulation of synaptic plasticity at a PNS vertebrate cholinergic synapse. Eur J Neurosci 18: 3241-3250, 2003.

RAHAMIMOFF R, YAARI Y: Delayed release of transmitter at the frog neuromuscular junction. $J$ Physiol Lond 228: 241-257, 1973.

RIBEIRO JA, CUNHA RA, CORREIA-DE-SÁ P, SEBASTIÃO AM: Purinergic regulation of acetylcholine release. Prog Brain Res 109: 231-241, 1996.

RIBEIRO JA, SEBASTIAO AM, DE MENDONCA A: Participation of adenosine receptors in neuroprotection. Drug News Perspect 16: 80-86, 2003.

SAWYNOK J: Adenosine and ATP receptors. Handb Exp Pharmacol 177: 309-328, 2007. 
SAMIGULLIN D, BUKHARAEVA EA, NIKOLSKY E, ADÁMEK S, VYSKOČIL F: Long release latencies are increased by acetylcholine at frog endplate. Physiol Res 52: 475-480. 2003.

SHAKIRZYANOVA AV, BUKHARAEVA EA, NIKOLSKY EE, GINIATULLIN RA: Negative cross-talk between presynaptic adenosine and acetylcholine receptors. Eur J Neurosci 24: 105-115, 2006.

SEARL TJ, SILINSKY EM. Modulation of $\mathrm{Ca}^{2+}$-dependent and $\mathrm{Ca}^{2+}$-independent miniature endplate potentials by phorbol ester and adenosine in frog. Br J Pharmacol 145: 954-962, 2005.

SILINSKY EM: Adenosine decreases both presynaptic calcium currents and neurotransmitter release at the mouse neuromuscular junction. J Physiol Lond 558: 389-401, 2004.

THOMAS S, ROBITAILLE R: Differential frequency-dependent regulation of transmitter release by endogenous nitric oxide at the amphibian neuromuscular synapse. J Neurosci 21: 1087-1095, 2001.

URAZAEV AK, MAGSUMOV ST, POLETAYEV GI, NIKOLSKY EE, VYSKOČIL F: Muscle NMDA receptors regulate the resting membrane potential through NO-synthase. Physiol Res 44: 205-208, 1995.

URAZAEV A, NAUMENKO NV, POLETAYEV GI, NIKOLSKY EE, VYSKOČIL F: Nitroprusside decreases the early post-denervation depolarization of diaphragm muscle fibres of the rat. Eur J Pharmacol 316: 219-222, 1996.

URAZAEV AK, NAUMENKO NV, POLETAYEV GI, NIKOLSKY EE, VYSKOČIL F: The effect of glutamate and inhibitors of NMDA receptors on postdenervation decrease of membrane potential in rat diaphragm. Mol Chem Neuropathol 33: 163-174, 1998.

URAZAEV AK, NAUMENKO NV, NIKOLSKY EE, VYSKOČIL F: The glutamate and carbachol effects on the early post-denervation depolarization in rat diaphragm are directed towards furosemide-sensitive chloride transport. Neurosci Res 33: 81-86, 1999.

VAN DER KLOOT W, MOLGÓ J, NAVES LA: Cholinergic agonists decrease quantal output at the frog neuromuscular junction by targeting a calcium channel blocked by omega-conotoxin. Pflugers Arch 434: 735-741, 1997.

VEGGETTI M, MUCHNIK S, LOSAVIO A: Effect of purines on calcium-independent acetylcholine release at the mouse neuromuscular junction. Neuroscience 154: 1324-1336, 2008.

VOSS AA: Extracellular ATP inhibits chloride channels in mature mammalian skeletal muscle by activating P2Y1 receptors. J Physiol Lond 587: 5739-5752, 2009.

VYSKOČIL F: Early postdenervation depolarization is controlled by acetylcholine and glutamate via nitric oxide regulation of the chloride transporter. Neurochem Res 28: 575-585, 2003.

VYSKOČIL F, NIKOLSKY E, EDWARDS C: An analysis of the mechanisms underlying the non-quantal release of acetylcholine at the mouse neuromuscular junction. Neuroscience 9: 429-435, 1983.

VYSKOČIL F, MALOMOUZH AI, NIKOLSKY EE: Non-quantal acetylcholine release at the neuromuscular junction. Physiol Res 58: 763-784, 2009. 